\title{
The Benzodiazepine Receptor: The Pharmacology of Emotion
}

\author{
H.A. ROBERTSON
}

SUMMARY: Anxiety seems to be an inherent and perhaps necessary component of civilization. However, the biological basis of anxiety has always been as obscure as the definition of anxiety itself. The importance of anxiety to our mental wellbeing was noted by Freud (1933) who considered it a "nodal point". As in the case of schizophrenia, there have been as many hypotheses to explain anxiety as there have been investigators with different techniques for studying it. The benzodiazepines,

RÉSUMÉ: L'anxiété est une composante inhérente es peut être nécessaire de la civilisation. Cependant la base biologique de lanxiété est toujours aussi obscure que sa définition elle-même. Freud (1933) considérait l'anxiété comme un point central. Comme pour la schizophrénie il existe autant d'hypothèse étiologiques que de chercheurs et de techniques disponibles. Les benzodiazepines, introduites en cli- introduced clinically in 1960, are now the most widely-used anxiolytic drugs. From the time of their introduction, it was felt that an explanation of the mode of action of benzodiazepines might shed considerable light on the basis of anxiety. The discovery, in 1977, of a specific benzodiazepine receptor, uniquely localized in the CNS, was the major turning point in this search (Squires and Braestrup, 1977; Mohler and Okada, 1977).

nique en 1960, sont maintenant les anxiolytiques les plus employés. Depuis le début on est convaincu que la compréhension de leur mode d'action pourrait jetter beaucoup de lumière sur les bases de l'anxiété. La découverte, en 1977 , des récepteurs spécifiques à la benzodiazepine est peut être le point tournant dans cette recherche (Squires et Braestrup, 1977; Mohler et Okada, 1977).
From the Department of Pharmacology, Dalhousie University, Halifax, Nova Scotia.

Reprint requests to H.A. Robertson, Department of Pharmacology, Sir Charles Tupper Medical Building. Dalhousie University, Halifax, Nova Scotia, Canada B3H 4 H7.
Characteristics of the Benzodiazepine Receptors

Binding of radioactive ligands $\left({ }^{3} \mathrm{H}\right.$ diazepam, ${ }^{3} \mathrm{H}$-flunitrazepam) to the benzodiazepine receptor in vitro is rapid, reversible, saturable, stereospecific and of high affinity. The affinity of a given benzodiazepine for the receptor is a good indication of its clinical and behavioral potency. For example, clonazepam with a $\mathrm{Ki}$ of 2 $\mathrm{nm}$ (high affinity) is therapeutically effective at a dose of $7.5 \mathrm{mg} /$ day while chlordiazepoxide, with a $\mathrm{Ki}$ of $570 \mathrm{nM}$ (low affinity) is therapeutically effective only at $100 \mathrm{mg} /$ day (Zbinden and Randall, 1967). Likewise, there is a significant correlation between the affinity of a benzodiazepine for the receptor and its ability to inhibit pentylenterazol-induced convulsions and a variety of other behaviors related to the pharmacological actions of the benzodiazepines (Squires and Braestrup, 1977; Mohler and Okada, 1977, Braestrup and Squires, 1978).

While benzodiazepine receptor is found throughout the CNS, the density of binding sites is highest in cortical areas and lowest in spinal cord (Squires and Braestrup, 1977; Mohler and Okada, 1977; Robertson et al, 1978). The similar distribution of $\gamma$-aminobutyric acid (GABA) receptors and a good deal of electrophysiological and biochemical evidence suggests that benzodiazepines act at a receptor which is associated with the GABA receptor. (Costa and Guidotti, 1979). This is not to say that the overlap is total and there is evidence that not all GABA receptors are associated with a benzodiazepine binding site (Young and Kuhar, 1979; Candy and Martin, 1979). Young and Kuhar (1979) suggested that benzodiazepine receptors were more widely distributed than GABA and other 
TABLE 1

Correlation Between Inhibition (Ki) of ${ }^{3} \mathrm{H}$-Diazepam Binding and Inhibition of Pentyletetrazol-induced Convulsions

\begin{tabular}{ccc} 
Compound & $\mathbf{K i}(\mathbf{n M})^{\prime}$ & $\begin{array}{c}\mathbf{E D}_{\text {s0 }} \mathrm{mg} / \mathrm{kg}, \text { p.o. } \\
\text { Mouse, Anti-pentylenetetrazol } \\
\text {-induced Convulsions }\end{array}$ \\
\hline
\end{tabular}

\begin{tabular}{lcl} 
Flunitrazepam & 3 & 0.1 \\
Clonazepam & 2 & 0.3 \\
Lorazepam & 3 & 0.4 \\
Diazepam & 9 & 2 \\
Flurazepam & 16 & 2 \\
Chlordiazepoxide & 570 & 8 \\
\hline
\end{tabular}

IData from Braestrup and Squires, 1978

'Data from Randall et al, 1974.

neurotransmitter receptors. Candy and Martin (1979) dissected bovine cerebellum into molecular and granular layers and were able to show that while the binding of $3 \mathrm{H}$-diazepam was approximately equal in the two layers, $3 \mathrm{H}$-muscimol binding in the granular layer was four times that in the molecular layer. This supports the idea that there is not a one-to-one relationship between benzodiazepine and GABA receptors.

While initial studies (Mohler and Okada, 1977) indicated that the benzodiazepine binding site was concentrated in the synaptosome, one subsequent study suggested a predominantly glial localization (Henn and Henke, 1978). Most workers currently agree that the receptors are predominantly neuronal (Tallman et al, 1980). Electrophysiological studies using cultured neurons tend to confirm this view (MacDonald and Barker, 1978). Recently, Mohler et al (1980) have used $3 \mathrm{H}$-flunitrazepam as a photo-affinity label in electron microscopic autoradiography and show most benzodiazepine receptors to be associated with synaptic contacts.

\section{Establishing a relationship between} benzodiazepine receptors and behavior

The best evidence that benzodiazepines produce their behavioral effects by interaction with the benzodiazepine receptor remains the observation that the behavioral potency of a benzodiazepine correlates well with its ability to displace $3 \mathrm{H}$-diazepam or $3 \mathrm{H}$-flunitrazepam from its binding site (Table 1).
Even more powerful evidence for the benzodiazepine receptor as a site of action is the stereospecificity shown by the receptor. The (+) enantiomers of two racemic benzodiazepines are potent both in displacing $3 \mathrm{H}$-diazepam and in modifying behavior while their (-) enantiomers are weak in both actions. These findings strongly support the idea that benzodiazepines have their pharmacological effects by an action at the benzodiazepine receptor.

The discovery of the benzodiazepine receptor and suggestions that an endogenous ligand might exist for this receptor has led to speculation that changes in benzodiazepine receptors might play a role in the development of anxiety states (Robertson et al, 1978; Robertson, 1979; Braestrup et al, 1979). We found that fearful Maudsley reactive rats have fewer benzodiazepine receptors than nonfearful Maudsley non-reactive rats (Robertson et al, 1978). Both strains are derived from a Wistar stock (Broadhurst, 1975). Similar results were obtained with inbred strains of mice (Robertson, 1979) and with the Roman high- and low-avoidance strains (unpublished data of $P$. Broadhurst, cited in Braestrup et al, 1979). These findings were of interest as there is much evidence, both in animals and man, for a genetic influence on phenomena related to anxiety (Marks and Lader, 1973). The results with experimental stress have not, however, been unequivocal. Lippa et al, (1978) reported that experimental stress produces a significant decrease in 3H-diazepam
TABLE 2 Association with Brain Areas

Possible Associated Effect

Anxiolytic

Anticonvulsant

Ataxia

Sleep Induction, Muscle Relaxation

Muscle Relaxation binding to rat cortex, a result that is in general agreement with the results obtained with inbred strains of rats (Robertson et al, 1978) and mice (Robertson, 1979). However, Braestrup et al, (1979) found that the effects of various experimental stresses on benzodiazepine binding were small and not unidirectional and Soubrie et al (1980) found that swim-stress in rats produced decreased cortical $3 \mathrm{H}$-flunitrazepam binding.

\section{Endogenous Ligands}

The existence of the benzodiazepine receptor and the inability of a large number of known or suspected neurotransmitters to interact with it has suggested, by analogy with the opiate receptor, the existence of an endogenous ligand. Furthermore, the actions of harmaline (Robertson, in preparation) and convulsant benzodiazepines (Schlosser and Franco, 1979) reinforces this idea. These compounds may be acting by displacing the endogenous ligand.

Among the suggested endogenous ligands are a large molecular weight protein (Colello et al, 1978), a purine (inosine or hypoxanthine) (Asano and Spector, 1979), nicotinamide (Mohler et al, 1979) and other compounds (Tallman et al, 1980). Another group of compounds being considered in our laboratory and elsewhere (Braestrup et al, 1980 ) is the $\beta$-carbolines, a family derived from the indoles and including harmaline. We (the author, G.B. Baker, R.T. Coutts, I.L. Martin and A. Benderley) have investigated a large 
number of $\beta$-carbolines and have found compounds which range in activity from worse than inosine $(\mathrm{Ki}$ approx. $1 \mathrm{mM}$ ) to better than clonazepam $(\mathrm{Ki}=4 \mathrm{nM})$. The nature of the endogenous ligand, however, remains unknown. It is worth noting that $\beta$-carbolines may be found in the CNS. Honecker and Rommelspacher (1978) have demonstrated tetrahydronorharmane in rat brain and urine while Shoemaker et al (1978) have shown the localization of $\beta$-carbolines to the hypothalamic arcuate nucleus. The formation of $\beta$-carbolines in vitro by a mechanism involving 5-methyltetrahydrofolic acid has been proposed (Wyatt et al, 1975). In summary, $\beta$-carbolines are very potent in displacing specifically bound $3 \mathrm{H}$-flunitrazepam. Some may be more potent than even clonazepam (Robertson et $a$, in preparation). $\beta$-Carbolines have been demonstrated in rat brain and a possible pathway of formation has been shown, at least in vitro. The identification of an endogenous ligand acting at the benzodiazepine receptor can be expected to cast considerable light on the biological basis of anxiety, convulsions and other disorders currently being treated with benzodiazepines.

\section{Implications and conclusions}

Since 1977, tremendous strides have been made towards an understanding of the mechanism of action of the benzodiazepines. The development of new techniques, for example, the autoradiographic procedures of Young and Kuhar (1979) and Mohler et al (1980), will allow us to see where the benzodiazepines work. The development of the benzodiazepine receptor binding assay now makes it feasible to rapidly screen large numbers of compounds for benzodiazepine-like activity. In such a screening procedure, we found $\beta$-carbolines had benzodiazepine-like activity. Other new nonbenzodiazepines with high affinity for the receptor and now known to have behavioral activity have been developed using the benzodiazepine binding assay as a screening procedure (Beer et al, 1978). The quantum leap we have taken since 1977 has obviously many important implications in the therapeutic use of the benzodiazepines and the development of new agents. However, this is not, I think, the most important advance that has been made. If we look down the list of the pharmacological actions of the benzodiazepines, we see they have many effects (Table 2). It seems that in gaining an understanding of the mechanism of action of the benzodiazepines, we will also cast considerable light on not only anxiety but on the fundamental mechanisms underlying seizures, sleep and other central phenomena.

\section{REFERENCES}

ASANO, T. and SPECTOR, S. (1979). Identification of Inosine and hypoxanthine as endogenous ligands for the brain benzodiazepine-binding sites. Proc. Natl. Acad. Sci. U.S.A. 75, 977-981.

BEER, B., KLEPNER, C.A., LIPPA, A.S. and SQUIRES, R.F. (1978). Enhancement of ${ }^{3} \mathrm{H}$-diazepam binding by SQ 65,396 : a novel anti-anxiety agent. Pharmacol. Biochem. Beh. 9, 849-851.

BRAESTRUP, C. and SQUIRES, R.F. (1978). Pharmacological characterization of Benzodiazepine Receptors in the Brain. European. J. Pharmacol. 48, 263-270.

BRAESTRUP, C., NIELSEN, M. and OLSEN, C.E. (1980). Urinary and brain $\beta$-carboline3-carboxylates as potent inhibitors of brain benzodiazepine receptors. Proc. Natl. Acad. Sci. U.S.A. 77, 2288-2292.

BRAESTRUP, C., NEILSEN, M., NIELSEN, B. and LYON, M. (1979). Benxodiazepine receptors in the brain as affected by different experimental stresses: The changes are small and not unidirectional. Psychopharmacology, 65, 273-277.

BROADHURST, P.L. (1975). The Maudsley reactive and non-reactive strains of rats: $A$ Survey. Behavior Genetics, 5, 299-319.

CANDY, J.C. and MARTIN, I.L. (1979). Distribution of muscimol and diazepam binding sites in the bovine cerebellar cortex. Proceedings Ist International Colloquim on Receptors neurotransmitters and peptide hormones. Capri, Italy. p. 123.

COSTA, E. and GUIDOTTI, A. (1979). Molecular mechanisms in the receptor action of benzodiazepines. Ann. Rev. Pharmacol. Toxicol. 19, 531-545.

FREUD, S. (1933). Introductory lectures on psycho-analysis. G. Allen \& Unwin. 2nd ed.

HENN, F.A. and HENKE, D.J. (1978). Cellular localization of $\left({ }^{3} \mathrm{H}\right)$-diazepam receptors. Neuropharmacology, 17, 985-988.

HONECKER, H. and ROMMELSPACHER, H. (1978). Tetrahydronorharmane (Tetrahydro- $\beta$-carboline) a physiologically occurring compound of indole metabolism. Naunyn-Schmiedeberg's Arch. Pharmaccl. $305,135-141$.
LIPPA, A.S., KLEPNER, C.A., YUNGER, L., SANO, M.C., SMITH, W.V. and BEER, B. (1978). Relationship between benzodiazepine receptors and experimental anxiety in rats. Pharmacol. Biochem. Beh. 9. 853-856.

MARKS, G. and LADER, M. (1973). Anxiety states (anxiety neurosis): a review. J. Ner. Ment. Dis. 156, 3-18.

McDONALD, R. and BARKER, J. (1978). Benzodiazepines specifically modulate GABAmediated post-synaptic inhibition in cultured mammalian neurons. Nature, 271, 563-564.

MOHLER, H. and OKADA, T. (1977). Benzodiazepine Receptor: Demonstration in the Central Nervous System. Science, 198, 849-851.

MOHLER, H., POLC, P., CUMIN, R., PIERI, L. and KETTLER, R. (1978). Nicotinamide is a brain constituent with benzodiazepinelike actions. Nature 278, 563-565.

MOHLER, H., BATTERSBY, M.K. and RICHARDS, J.G. (1980). Benzodiazepine receptor protein identified and visualized in brain tissue by a photoaffinity label. Proc. Natl. Acad. Sci. U.S.A., 77, 1666-1670.

ROBERTSON, H.A. (1979). Benzodiazepine receptors in "emotional" and "non-emotional" mice: comparison of four strains. European J. Pharmacol. 56, 163-166.

ROBERTSON, H.A., MARTIN, I.L. and CANDY, J.M. Differences in benzodiazepine receptor binding in Maudsley reactive and Maudsley non-reactive rats. European J. Pharmacol. 50, 455-457.

SCHLOSSER, W. and FRANCO, S. (1979). Reduction of $\gamma$-aminobutyric acid (GABA)mediated transmission by a convulsant benzodiazepine. J. Pharmacol. Exp. Therap. 211, 290-295.

SHOEMAKER, D.W., CUMMINGS, J.T. and BIDDER, T.G. (1979). $\beta$-Carbolines in rat arcuate nucleus. Neuroscience 3, 233-239.

SOUBRIE, P., THIEBOT, M.H., JOBERT, A., MONTASTRUC, J.L., HERY, F, and HAMON, M. (1980). Decreased convulsant potency of picrotoxin and pentetrazol and enhanced ${ }^{3} \mathrm{H}$-flunitrazepam cortical binding following stressful manipulations in rats. Brain Res. 189, 505-517.

SQUIRES, R.F. and BRAESTRUP, C. (1977). Benzodiazepine receptors in rat brain. Nature, 266, 732-734.

TALLMAN, J.F., PAUL, S.M., SKOLNICK, P. and GALLAGER, D.W. (1980). Receptors for the age of anxiety: Pharmacology of the benzodiazepines. Science, 207, 274-281.

WYATT, R.J., ERDELYI, E., DOMARAL, J.R., ELLIOT, G.R., RENSON, J. and BARCHAS, J.D. (1975). Tryptoline formation by a preparation from brain with 5 methyltetrahydrofolic acid and tryptamine. Science 187, 853-855.

YOUNG, W.S., III and KUHAR, M.J. (1979). Autoradiographic localization of benzodiazepine receptor in the brains of humans and animals. Nature, 280, 393-395.

ZBINDEN, G. and RANDALL, L.O. (1967). Pharmacology of benzodiazepines: Laboratory and clinical correlations. Adv. Pharmacol. Chemother. 5, 213-291. 